\title{
2108 山形県吉野鉱山産黒鉱鉱石の釷石顕微鏡的研究
}

早稲田大学大学院理工学研究科 ○渡 辺 則 道(淮会員)
地質調查所鉱床部金属課 北 $\quad$ 卓 治

\section{1. まえがき}

吉野鉱山（日本鉱業株式会社）は山形県南陽市荻にあ り，その鉱床は古くから墅鉱鉱床として著名である。昭 和 41 年, この鉱山を中心とした約 $300 \mathrm{~km}^{2}$ の地域(山 形盆地々米沃盆地々を境する地域) 飞, 通商産業省鉱山 局の事業の一環として, 金属鉱物挆鉱促進事業団により 広域調査が実施された。その結果, この山形吉野地域が 南北二つの積成盆地をかくする構造の高まった、基盤の 隆起地域にあたることが明らかとなった。筆者らは、こ の吉野鉱山の黒鉱について鉱石顕微鏡扣よび電子プロブX線マイクロアナライザーによる研究を進めつつある が,ここにその研究結果の概要を報告する。

\section{2. 地質}

吉野鉱山周辺には先新第三紀花崗閃緑岩を基盤とする 新第三系が広く分布し、下位上り上位に向って太郎層, 吉野層, 長谷堂層, 呑岡山層, 葉山層の五層に分けるこ とができる゙。北西部は, 第四紀の白鷹山火山泥流により 扣执われている。

新第三系の基盤である花崗閃緑岩は, 南部に広く分布 するほか, 小岩体が, 鉱山北東部飞点在している。これ ら花崗閃緑岩を不整合飞招扣了最下部の太郎層は, 上中 下三部層に分けられる。下部層は砂岩・碟岩, 中部層は 変質安山岩溶岩と同質凝死岩類, 上部層はアルコーズ質 砂岩ないし凝灰質砂岩より成る。下部層の分布は非常に せまく，中部層が直接基盤を扣扣了場合が多い。太郎層 に整合に重なる吉野層は凝灰岩類を主体と.し, 上下の二 部首に分けられる。下部層は安山岩〜石英安山岩質凝灰 岩類扣よび同質溶岩によって特長づけられ,この地域の 黒鉱鉱床の母岩となっている。上部層は流紋岩質凝灰岩 類を主体とし, 北東部に広く分布している。長谷堂層は 凝灰質砂岩・泥岩を主として北部に分布する。吞岡山層 は主として石英安山岩溶岩より成り, 北北東部に分布す る。葉山層は凝灭質砂岩・泥岩よりなり, 亜炭層を夾在 し，北西部にわずかに分布するにすぎない。

この地域の地質構造は, NNE-S SW 性構造方向と $\mathrm{NW}-\mathrm{SE}$ E性構造方向が顕著に現われ, ベーズン構造を褶 曲構造扣よび断層構造が修飾している。 NNE-S SW 性 の構造は波長の小さい褶曲構造で代表され, NW-SE性 構造は波長の大きい裮曲構造である。

\section{3. 鉱 床}

吉野鉱山では, 現在, 吉野本鉱体, 日坂第五鉱体を中 心に稼行しているが, 吉野本鉱体周辺にはすでに採掘を 終了した恵比須, 大黒, 布袋, 水草などの鉱体が, ごく 近接して分布している。鉱床は層状を示す黒鉱鉱床で吉 野層下部層の凝灰岩類中に胚胎している。鉱床付近には 小ドーム構造扣よび背斜構造が多く発達するが, 鉱床は それらの翼部に位置している。

鉱床上盤には雑色を呈する粘土（いわゆる松皮粘土） が存在し, 鉱石は鉱体上部より黒鉱, 黄鉱, 珪鉱の順に

* 男鹿半島の層序飞対比すると, 太郎一台島, 吉野一西黑沢, 長 谷堂一女川, 吞岡山一船川 北浦, 葉山一脇本である。

$200<40>$

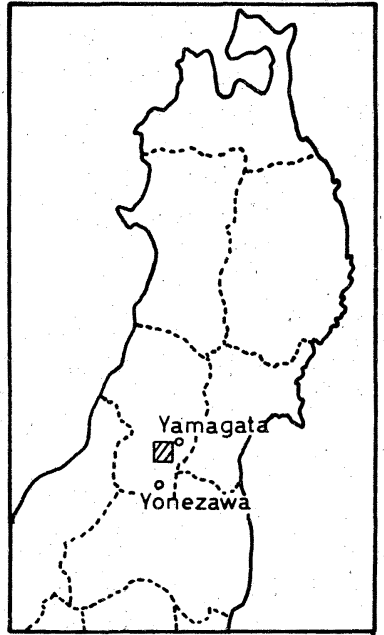

第1図 吉野鉱山位置図 斜線部は, 昭和 41年庆域調查少 行われた地域て 吉野鉱山はその 中央部几位置寸 る。

帯状分布を示している。

\section{4. 鉱石の鉱物組成}

これらの鉱石を鉱石顕微鏡下で観察すると, その主成 分をなしてごく普遍的な鉱石構成鉱物として黄鉄鉱, 黄 銅鉱, 閃亜鉛鉱, 方鉛鉱, 四面銅鉱のほか, 少量の従成 分鉱物としての斑銅鉱, 輝銅鉱, 硫砒銅鉱, ユベリン, 白鉄鉱, 自然金 (エレクトラム), アイダ鉱 (?)が認め られる。

(1)黄鉄鉱：黄鉄鉱には 2 種類があり,その一つは結晶 度が高く自形を呈し，も5一つはゲル構造を示し他の構 物と不規則に入り混り，しばしばコロフォーム組織をも つものである。しかしながら両者の中間型も種々みられ 2 つの型の黄鉄鉱の産状飞規則性はない。第 1 の型の黄 鉄鉱中には, とされ米粒状の自然金（エレクトラム）が 含まれる。

(2)黄銅鉱・閃亜鉛鉱・方鉛鉱：3 者は密接な共生関係 をもち，量の多少はあっても普遍的に見られる。とくに 黄銅鉱一閃亜鉛鉱, 閃垔鉛鉱一方鉛鉱の共生は顕著であ る。閃亜鉛鉱中には黄銅鉱が点滴状に含まれる場合が多 いが, 点滴状とは表現し難い細長い破片状に含まれる場 合もある。これて対し黄銅鉱中に閃亜鉛鉱が含まれる場 合は粒状を呈する。一部では黄銅鉱, 閃亜鉛鉱が黄鉄鉱 とともにゲル構造を示す。閃亜鉛鉱が方鉛鉱に交代され た構造もみられるが, 両者は同時晶出と思われる組織を 示すことが多い。

(3)四面銅鉱：鉱石全般飞わたって少量ではあるが認め られる。閃亜鉛鉱, 方鉛鉱と密接な共生関係を示すが, 一部では黄銅鉱と共生している。このほか自然金, 脈石 （石英?）と共生し, 後期晶出と考兄られるるのがある。

(4)斑銅鉱：初生斑銅鉱と二次斑銅鉱々が存在する初生 斑銅鉱は, 黄銅鉱と格子状離溶組織を示し, 黄銅鉱, 閃 亜鉛鉱中にみられる。二次斑銅鉱は黄銅鉱の周縁部また 
は割目に沿い, 内部に向って“ひげ”状に分布し, ある いはコロフォーム構造を示す黄鉄鉱, 黄銅鉱中に網目状 をなして存在する。辉銅鉱と密接飞共生する場合が多い。

(5)硫砒銅鉱：ゲル構造を示す黄鉄鉱, 閃曲鉛鉱, 方鉛 鉱と輝銅鉱が存在している部分に, 不規則アメ一; 状を

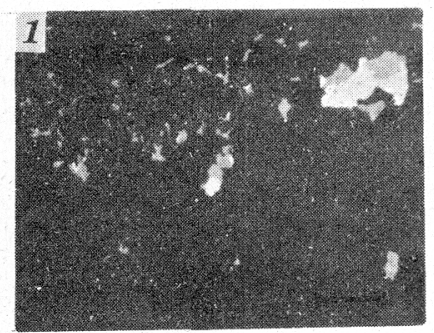

1 : 産状 d) に市たる 自然金 (白色部)，灰 色部は四面銅鏣, 周囲 は閃垔鉛錙。

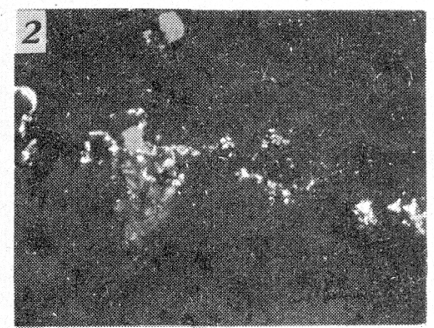

2：産状e)にあたる 自然金(白色部)，灰 色部は閃亜鉛䤲, 周囲 は眽石。

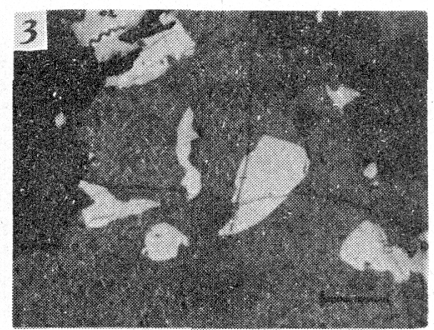

3 : 斑銅鉱と黄銅鉱の 離溶組織。格子状老索 すのと, 灰白色部は黄 銅鉱，それらの間をち める在色部が斑銅鉏， 暗黑部は脈石, 脈石周 辺に暗灭色を示してい るのは間覀鉛鉱。

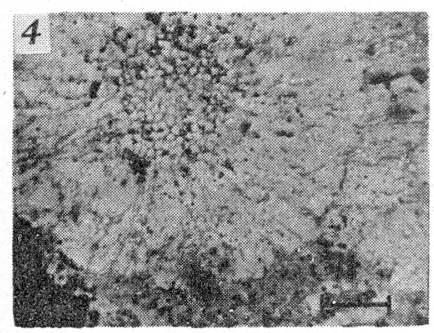

$4:$ :コフォーム組織 老示黄鉄鏣，黄銅鉱， 閃互鉛鉱。中心部は> ランボイド組織を示す 黄鉄鉱。
なして産する。しかし，その産出はまれである。

(6)白鉄鉱：閃覀鉛鉱, 方鉛鉱, 斑銅鉱, 黄鉄鉱, コへ リンとさわめて密接な共生関係を示し, 丸味を执びた粒 状をなす。産出は非常に限られているようで,ただ 1 個 の研摩片に認められるにすぎい。

この白鉄鉱の共生鉱物集合体の5ち, 1 力所で斑銅鉱 中に顕著な異方性と反射多色性を示し, 針状〜長柱状の 微晶 $(10 \mu$ 程度) がみらられたこの鉱物はその光学性, 共生鉱物からアイダ鉱と推定した。

(7)自然金（エレクトラム）：鉱石全般を通じて，自然 金(エレクトラム)の産出はそうまれではないが, 局所 に濃集する傾向が認められる。これを産状により分ける と，次のと扣りである。

a) 自形黄鉄鉱飞米粒状に含まれるあの。

b）黄銅鉱中にほぼ円形をなして含まれるもの。

c）閃哑鉛鉱中に粒状で含まれるもの。

d）閃业鉛鉱中にアメ一- 状微細四面銅鉱の集合が, 脈状をなしている部分に四面銅鉱と閃亜鉛鉱に接して, 不規則な形をもって産するもの。

e）脈石中飞細脈子なす脈石（石英？）飞伴われて， 系くず状飞脈石粒間を墁めて産するもの。

金粒の色調にはかなり変化があるが, 産状との関連に ついては，規則性は認められない。観察された自然金 (エレクトラム)の最大の大きさは $30 \mu て ゙, \quad 5 \sim 15 \mu$ のもの泣普通である。

\section{5. 鉱 石 組 織}

黑鉱鉱石で一般飞認められるコロフォーム粗織, フラ ンボイド組織, 点滴状組織などが吉野鉱山産鉱石飞打い ても普通飞認められる。斑銅鉱と黄銅鉱は離溶組織を示 के

\section{6.むす び}

これまで北鹿地方の黒鉱鉱㦿についてはかなり多くの 鉱石顕微鏡的記載が行なわれているが，ほかの地域の鉱 石についての記載は非常に之しい。筆者らは, この観点 から吉野鉱山産黒鉱についての研究を行なったのである が,すでに述べたように, その鉱石構成鉱物の種類と共 生組織はすでに報告された北鹿地方のものとはなはだよ く似ている。

今回の研究によって金の賦存状態がかなり明らかにな ったが，とくに注目をひくことは自然金，四面銅鉱，脈 石（石英？）が，後期飞早期晶出鉱物を交代したと考党 られる点である。

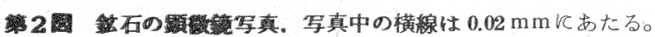

\section{9 鉄ーチタン酸化鉱物のEPMAによる研究 とくに結果の補正について}

東京大学工学部助手藤 木 良規(正会員)

1. 緒

言

種々火成岩類および砂鉄鉱床に打ける鉄チタン酸化鉱 物の火成岩類と化学組成, 離溶組織と化学組成なぞの関 係飞ついて反射顕微鏡下の観察と EPMA に上る定量分析 を併用して研究しているが, 今回は鹿児島県下さつま半
島南部の指宿一閒聞岳付近の火成岩類および䐊児島湾海 底砂鉄と種子島の海浜砂鉄鉱床より採取した磁鉄鉱, 千 タン鉄鉱, 赤鉄鉱などの化学組成飞ついて報告する。

またこれに関連してとくに分析補正の問題について検 討した。

Vol. 84 No. 959 ('68-3) 